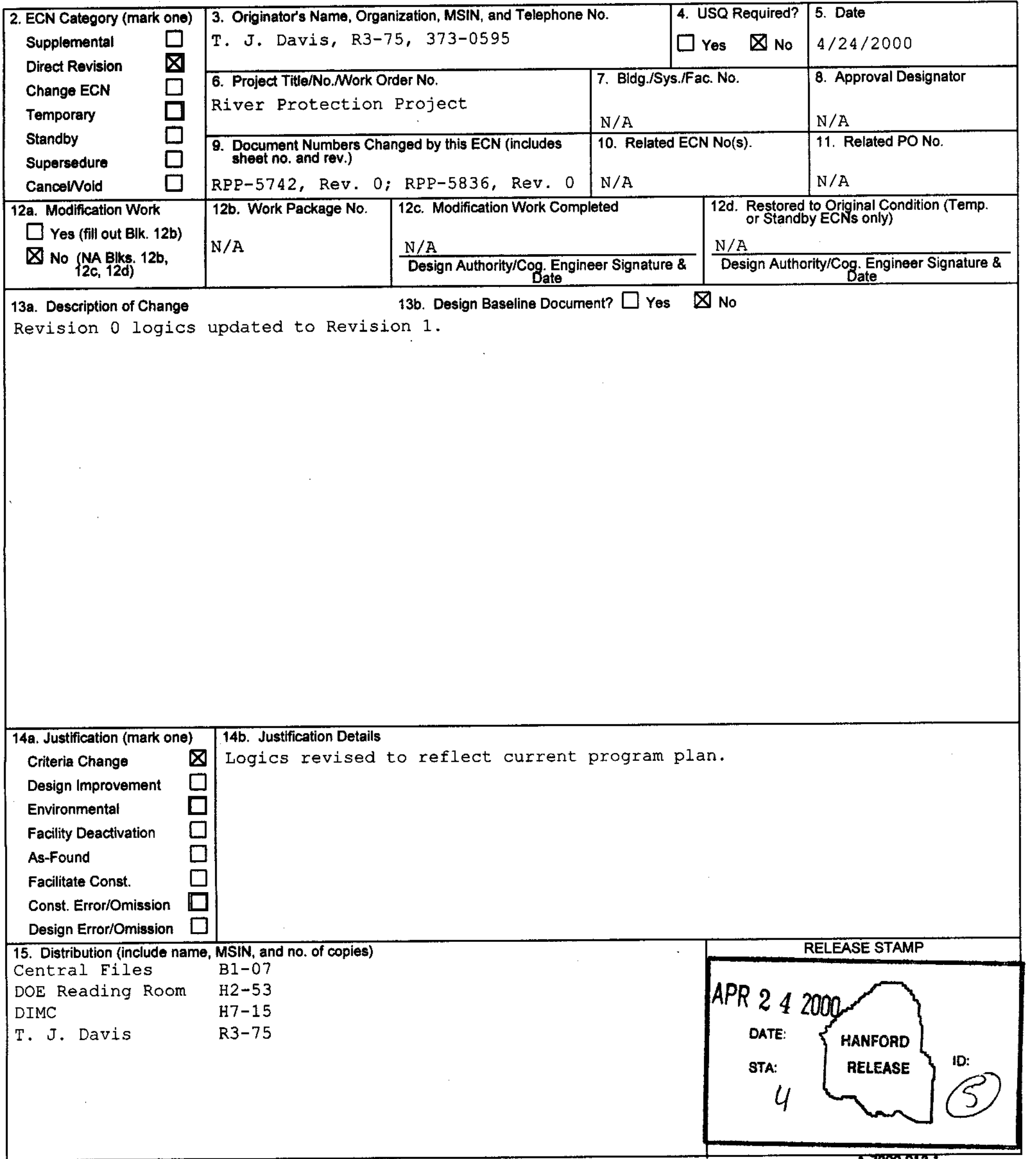




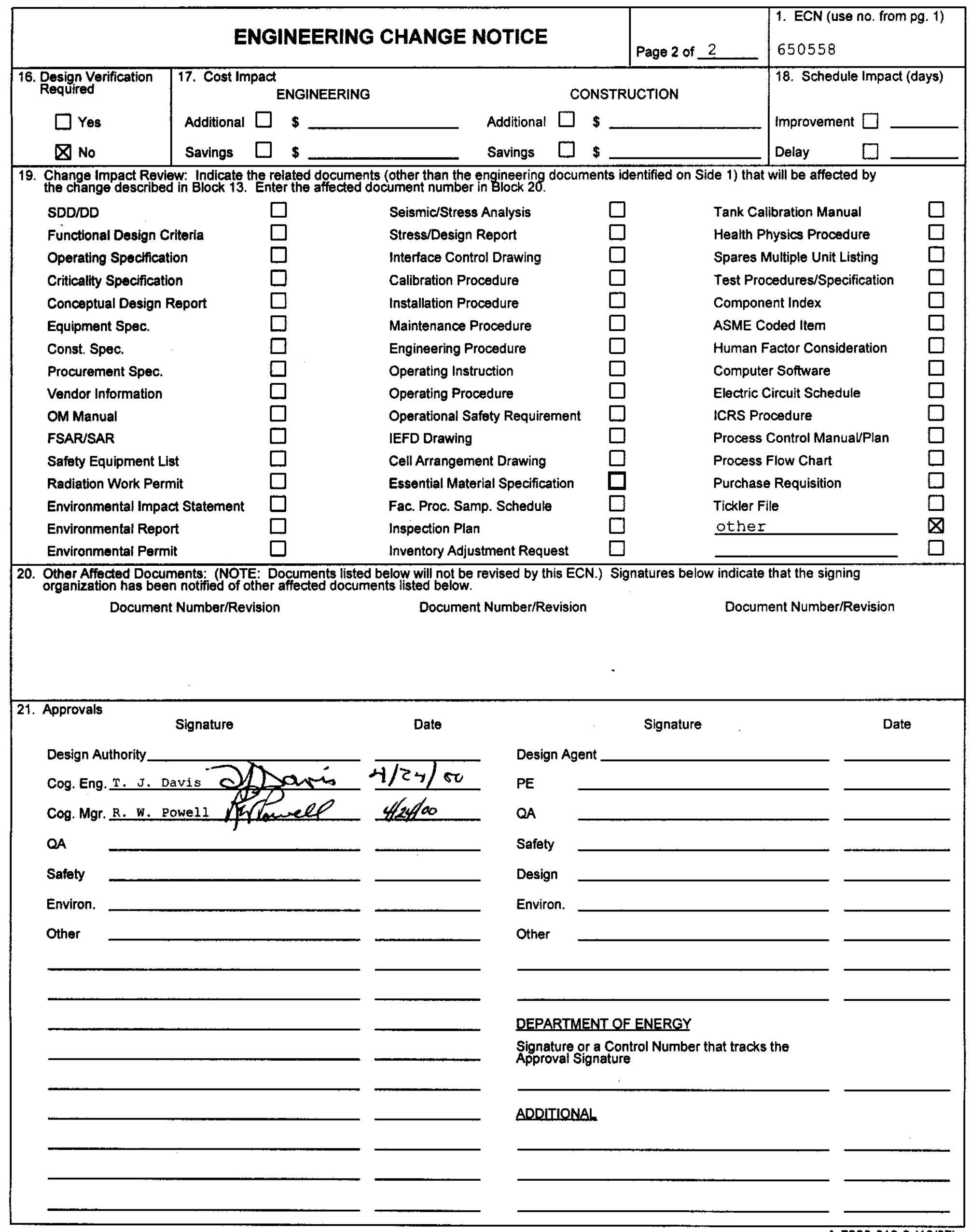




\title{
Tank Farm Contractor, Phase 1, Feed Delivery Storage and Disposal Mission Summary for 2006 Hot Start
}

\author{
T. J. Davis \\ CH2MHILL Hanford Group, Inc.
}

Richland, WA 99352

U.S. Department of Energy Contract DE-AC06-99RL14047

\author{
EDT/ECN: $650558 \quad$ UC: 721 \\ Cost Center: 7C400 Charge Code: 106412 \\ B\&R Code: \\ Total Pages: 3
}

Key Words:

Level One Logic, WED, Mission Summary

\section{Abstract:}

This is the level one logic diagram for the River Protection Project (RPP), Tank Farm Contractor, Phase 1, Feed Delivery Storage and Disposal Mission Summary for 2006 Hot start.

TRADEMARK DISCLAIMER. Reference herein to any specific commercial product, process, or service by trade name, trademark, manufacturer, or otherwise, does not necessarily constitute or imply its endorsement, recommendation, or favoring by the United States Government or any agency thereof or its contractors or subcontractors.

Printed in the United States of America. To obtain copies of this document, contact: Document Control Services, P.O. Box 950, Mailstop H6-08, Richland WA 99352, Phone (509) 372-2420; Fax (509) 376-4989.
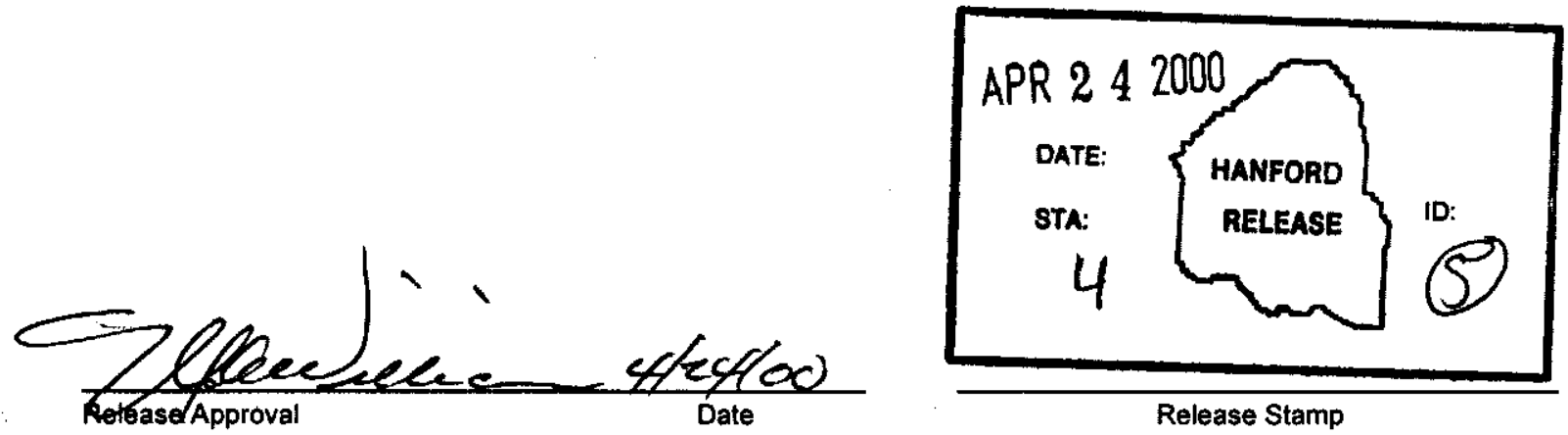

Release Stamp

\section{Approved For Public Release}




\section{RECORD OF REVISION}

(2) Title

Tank Farm Contractor, Phase 1, Feed Delivery Storage and Disposal Mission Summary for 2006 Hot Start

\section{Change Control Record}

(3) Revision

(4) Description of Change - Replace, Add, and Delete Pages

(7)

Initial Release, EDT-625316

$4 / 24 / 00$, ECN 650558

\begin{tabular}{l|l}
\hline (1) Document Number & \\
RPP-5742 & Page 1 \\
\hline
\end{tabular}

Page 1 .

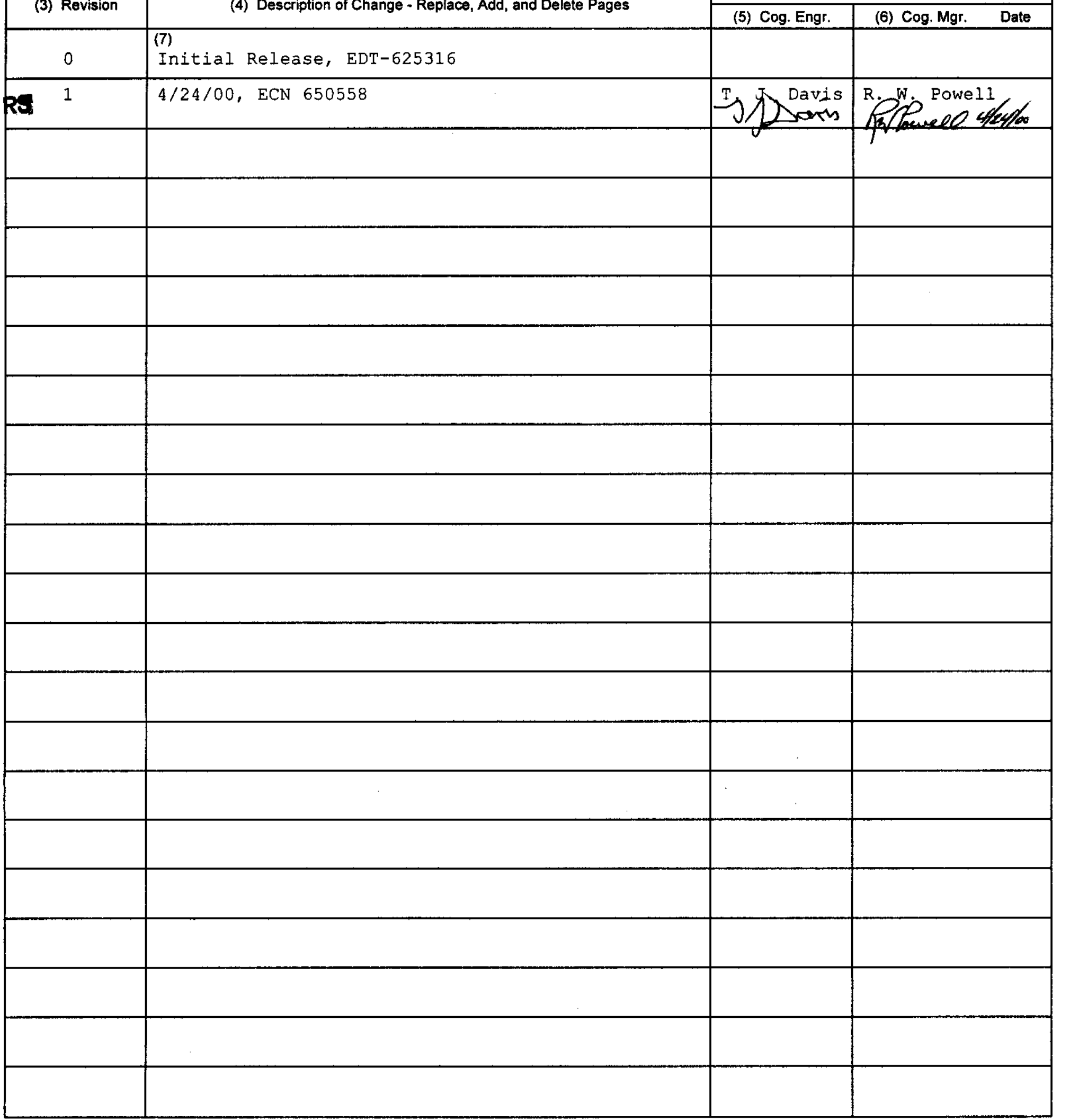




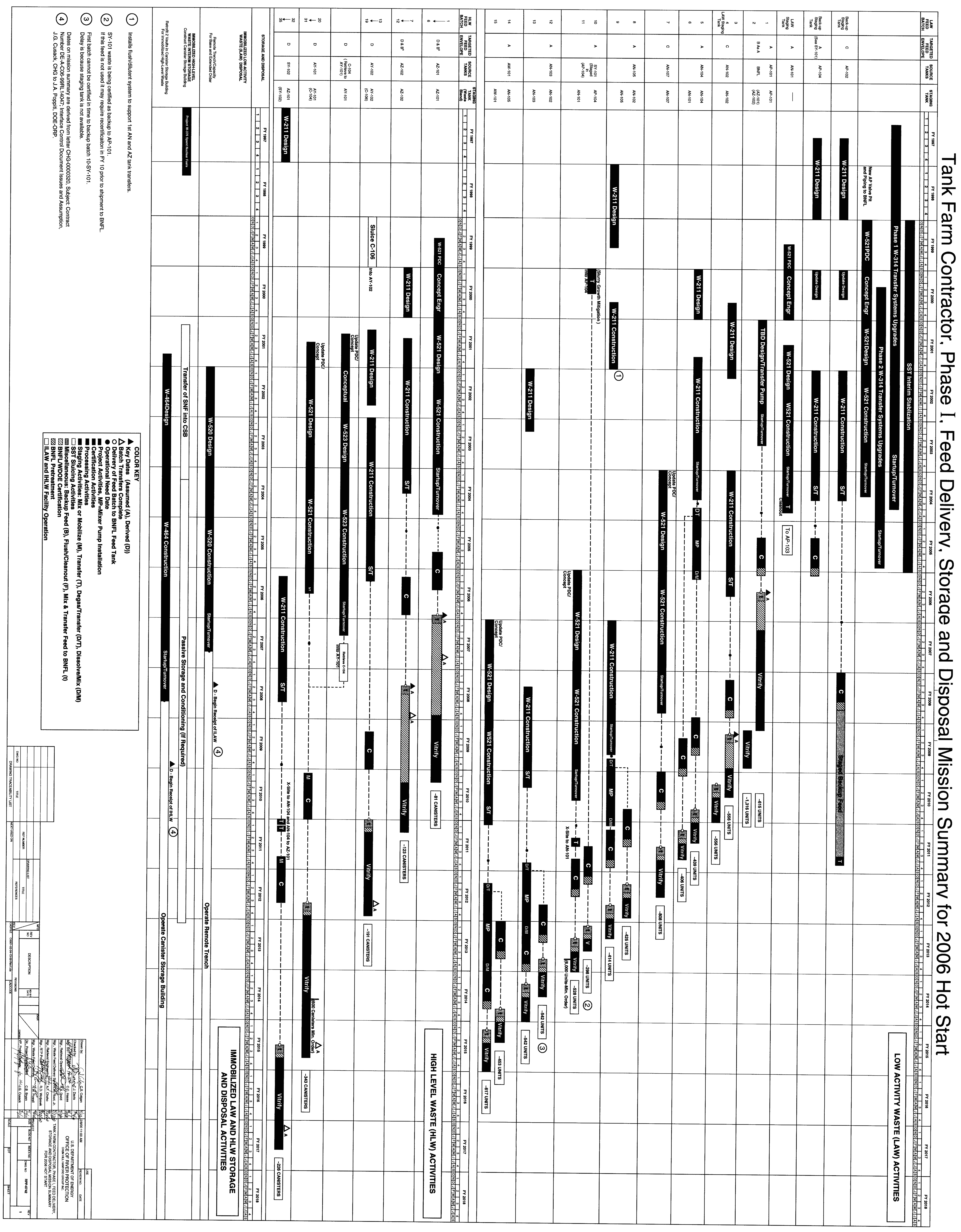

